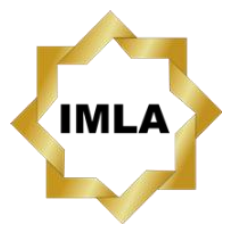

Available online:

http://journal.imla.or.id/index.php/arabi

Arabi : Journal of Arabic Studies, 5 (1), 2020, 51-62

DOI: http://dx.doi.org/10.24865/ajas.v5i1.249

\title{
THE MANAGEMENT OF LANGUAGE LABORATORY IN IMPROVING STUDENTS ARABIC COMPETENCE
}

\author{
Wahyudi Buska, Mukhtar Latif, Risnita, Kasful Anwar Us, Yogia Prihartini \\ Universitas Islam Negeri Sulthan Thaha Saifuddin Jambi, Indonesia \\ E-mail : wahyudi@uinjambi.ac.id
}

\begin{abstract}
This study aimed to describe the success of the management of a language laboratory in improving students' Arabic language competence. This was a qualitative descriptive study. The research findings show that the language learning process through the laboratory increased the students' listening and speaking skill. The language learning process through the laboratory was supported by extracurricular activities. This activity also had a positive impact on language learning achievement of students who previously did not understand Arabic. Then, laboratory as a place for accommodating students' talent such as laboratories was very helpful for students in the learning process; this was because the students could communicate directly with native speakers. The implementation of the development of teaching and learning activities using the Arabic language laboratory was directed to students through inservice training programs. The evaluation program was conducted by Arabic language lecturers to see the level of achievement obtained by students after finishing studying in two ways, namely competitive and non-competitive.
\end{abstract}

Keywords: language laboratory, management, Arabic, competence

\begin{abstract}
Abstrak
Penelitian ini bertujuan untuk menggambarkan keberhasilan pengelolaan laboratorium bahasa dalam meningkatkan kompetensi bahasa Arab mahasiswa. Penelitian ini adalah penelitian deskriptif kualitatif. Temuan penelitian tentang keberhasilan manajemen laboratorium bahasa menunjukkan bahwa: Pertama, hasil penelitian menunjukkan bahwa proses pembelajaran bahasa melalui laboratorium terdapat peningkatan kompetensi mendengarkan dan berbicara mahasiswa. Kedua, proses pembelajaran bahasa melalui laboratorium didukung oleh kegiatan ekstrakurikuler. Kegiatan ini juga memiliki dampak positif pada prestasi belajar bahasa mahasiswa untuk mengerti bahasa Arab. Ketiga, tempat penyaluran bakat mahasiswa seperti laboratorium sangat membantu siswa dalam proses pembelajaran. Hal ini karena siswa dapat berkomunikasi langsung dengan penutur asli Keempat, implementasi pengembangan kegiatan belajar mengajar menggunakan laboratorium bahasa Arab diarahkan kepada mahasiswa melalui program pelatihan. Kelima, program evaluasi dilakukan oleh dosen bahasa Arab untuk melihat tingkat prestasi yang diperoleh mahasiswa setelah menyelesaikan studi dengan dua cara, yaitu tes kompetitif dan non-kompetitif.
\end{abstract}

Kata Kunci: laboratorium bahasa, manajemen, bahasa Arab, kompetensi 


\section{Arabi : Journal of Arabic Studies}

\section{Introduction}

The adoption and utilization of educational technology in the developing countries face many difficulties in the educational system and it does not always lead directly proportional increases in student learning outcomes. Therefore, it is very important to investigate and understand the critical success factors in order to optimize student outcomes (Kashada, Li, \& Koshadah, 2018; Albantani, 2018). The use of language laboratories in learning is a concrete manifestation of the use of technology in lectures. Integrating technology into foreign language instruction in the digital era is unquestionably vital and scientifically suggested (Albantani \& Madkur, 2019).

The laboratory was conceived as the spearhead of education, research and community service at a tertiary institution in order to produce outputs that are not only capable in theory but also capable in practical aspects. It is a room for practicum/practice or research activities supported by the existence of a set of laboratory equipment as well as the existence of a complete laboratory infrastructure or in accordance with the type of laboratory itself. There are benefits of laboratory activities, such as (1) to motivate and strengthen the interests and the activity of prospective teachers; (2) to train the skills to work in a laboratory; (3) to assist the understanding and (4) development of concepts; (5) to inculcate the scientific attitude (Coffey, Elby, \& Levin in Rosita, 2016). The laboratory has been given a central and distinctive role in science education, and the educators have suggested the rich benefits in learning accrue from using laboratory activities (Hofstein, et.al, 2004).

The laboratory is one of the learning facilities in higher education institutions as a place for practicum activities for students. Whereas for language courses both in the language department and in non-language majors, the laboratory has a very important role for the implementation of language practice, especially foreign languages that are not found to be applied in everyday life by students.

Related to the importance of the existence of educational laboratories in tertiary institutions, a comprehensive management system is needed to describe all activities related to the function of the laboratory itself, and to facilitate the use of laboratories in teaching and learning activities on campus. In order to optimize the function and purpose of the existence of a language laboratory, IAIN Kerinci has made various efforts in the management of laboratories such as procurement of facilities and infrastructure, improvement of facilities, addition of equipment and enhancing the ability of managers. The efforts undertaken by the university are evidence of the institution's attention to aspects of laboratory management as one of the priority scales for achieving the goal of higher education nationally.

The quality of education is influenced by many factors, including the availability of adequate educational infrastructure and competent human resources (Prihartini, 2019). Both are very important input components in supporting learning activities. Therefore, it is necessary to improve the quantity, quality, and management system. One of the educational facilities that serves as a support in the implementation of the learning process in schools, especially those related to practicum/practice is the language laboratory (Leite, 2013).

Language laboratory is a supporting device for the implementation of education in study programs in academic and/or professional education. This laboratory functions as a supporting facility to carry out education, research and teaching in one or a number of branches of science and technology in accordance with the field of study concerned, particularly regarding language. Language laboratory is a facility to practice linguistic materials in accordance with the characteristics of the four language competencies (reading, speaking, listening, writing). Language laboratories are study rooms equipped with electronic sound-reproduction devices, enabling students to hear model pronunciations of foreign languages and to record and hear their own voices. The language laboratory is an audio or audio-visual installation used as an aid in modern language learning (Ramganesh \& Janaki, 2017).

Vol. 5 No. 1 | $52-62$

Copyright (C) 2020 | ARABI | p-ISSN 2548-6616 | e-ISSN 2548-6624 
The language laboratory functions as a place for learning activities that require special equipment that is not easily presented in the classroom. In other words, the language laboratory functions as a place of learners in an effort to improve students' language proficiency in the form of a learning process. Therefore, the head of UPB / P2B, managers, language instructors, and other related elements must be able to manage and utilize language laboratories effectively and efficiently, so as to improve the quality of the process and results of language learning for these students.

Language laboratories are also part of educational facilities which have an important role in supporting teaching and learning activities. To avoid the uselessness of the laboratory, it is necessary to strive for management and empowerment in accordance with the requirements outlined. Management of the language laboratory in terms of its existence is one of the educational facilities that can be utilized as a support in teaching and learning activities. In order for a language laboratory to be useful for teaching and learning activities, all components contained therein must be managed effectively (Vanderplank, 2010). Effective management of a language laboratory can be seen from the functionality of the language laboratory as a source of learning, educational method, and educational infrastructure. With the functionality of the language laboratory it is hoped that it will have an impact on improving the quality of education, which is characterized by an increase in the performance of the learning process and learning outcomes achieved by students (Wagener, 2006).

The form of laboratory management essentially includes planning, organizing, actuating, controlling, and evaluating. The planning activities include the laboratory work program, the preparation time of the laboratory work program, the process of preparing the activity plan, planning the management staff and developing their capabilities, planning of facilities, tools, materials, and costs, as well as planning of laboratory development. Then organizing activities can be seen from the organizational structure, job description and implementation tasks, terms of work, responsibilities, and organizing facilities. The implementation activities are seen from the coordination of the laboratory manager with the lecturer, the implementation of laboratory management's activities to serve the needs of teaching and learning activities, and the optimization of the use of facilities' tools and materials that are appropriate with the language laboratory administration (Berte, 2007). The supervision activities include the supervisor and supervisory techniques as well as the time of supervision used. Finally, the evaluation activities are the evaluation itself and the time used.

Management of language laboratories is an effort to achieve goals by utilizing human resources, information, systems, and funding sources while still paying attention to the functions, management, roles and management expertise. In this case, the laboratory is expected to be able to increase the interest and enthusiasm of teaching lecturers and learners, but at present many language laboratories at the university have not been used optimally (Allen, 2013). This is due to lack of interest, knowledge of management and use in the utilization of human resources in the laboratory. Use of language laboratories adapted to the needs of their user. To use the laboratory as a means of supporting the teaching and learning process in higher education it should be well managed (Fulga, 2013).

The low utilization of language laboratories in tertiary institutions as a means of supporting the learning process is one of the inhibiting factors in increasing ability or skills. By implementing a learning process that utilizes a laboratory or practice room, in the use of laboratories, it is expected that students will be able to master the subject matter, not only through theory alone, but also through practice. The existence of a language laboratory at a tertiary institution has a large role in the teaching and learning process. This is due to the many learning facilities or media that are not in the classroom or only available in the language laboratory. Management of language laboratories in the teaching and learning process must always be in a ready-made condition, the 


\section{Arabi : Journal of Arabic Studies}

presence of facilities or media in it must also be in good condition and equipped with a variety of effective administration (Tobin, 1990).

The condition of laboratory equipment which is usually used for practicum is also an important factor for the success of laboratory management. Specifically in the language laboratory, equipment is still very limited and does not meet applicable standards, where at each change of semester must change the existing system and adjust to the curriculum scheduled for that semester. Another fact found based on preliminary observations shows that the organization and coordination system that has not been implemented properly has resulted in laboratory activities not running properly. Therefore, language laboratories need to be improved in terms of facilities such as equipment in this case computers, and in terms of infrastructure such as rooms or classrooms that do not meet the Minimum Laboratory Standards (SML).

We cannot deny that the effectiveness of language laboratories on campuses is currently very low and depends on the ability and intelligence of the teaching team and head of the laboratory in managing it (Marzuki, 2014). In other words, currently the language laboratory has not been managed as an effective learning media by the teaching teams in supporting language improvement. Although many modern facilities are now well-equipped, these facilities are rarely used because most language lecturers do not know how to optimally utilize and operate the media.

The laboratory has an important role in the process of teaching and learning foreign languages. First, language laboratories offer language learning with several possible benefits such as listening, writing, speaking and copying the native speech model. Another reason for the advantages of language laboratories is that learning foreign languages is very important for learners to not only understand the language mentally, but learners also gain practice, especially in large classes where it is difficult for a lecturer to give each learner practice adequately and control his accuracy.

Therefore, the language laboratory is a room designed for foreign language learning. In general, it is equipped with several electronic devices that are used as a medium for learning foreign languages (Marzuki, 2014). However, along with the times, language laboratories are also able to support communicative learning, which emphasizes long-term learning, interdisciplinary between various subjects of discipline, student-focused, and integrated with everyday problems and realities. Based on some of the above it can be seen that the language laboratory is a room equipped with several electronic devices designed not only as a medium for foreign language learning but also able to support communicative learning, which emphasizes long-term learning, interdisciplinary between disciplines, focused on students, and integrated with everyday problems and realities.

\section{Method}

This research used descriptive analysis method with a qualitative approach. Descriptive method aims to obtain information about the implementation of laboratory management studies as a learning resource to improve Arabic language skills. This research aimed to describe clearly the planning, implementation, supervision, and management of the language laboratory in improving language competence at IAIN Kerinci. The description of this research is emphasizing the process of the results and using natural sources as a source of direct data means trying to understand from the point of view of objects that experience what is happening because in this case what is observed is the extent to which language laboratory management is carried out in order to support the learning process at IAIN Kerinci. The research model used was the POAC (Planning, Organizing, Actuating, Controlling or evaluating) model proposed by George R. Terry on the application of language laboratory management in improving language skills. (Grunig, 2006). This research reveals the reality of the planning, implementation and supervision of language laboratory management in supporting the language teaching process at IAIN Kerinci. 
The research took place at the IAIN Kerinci Language Laboratory. The research subjects were the people who are considered the most knowledgeable and are actively involved in managing the language laboratory, namely head of the UPB or manager of the language laboratory, Secretary and concurrently the coordinator of the language laboratory, Arabic or English lecturer and students. The object of this research was the facilities and documentation of the language laboratory. The selection of research subjects is based on a purposive sampling technique. It means that the subjects were chosen based on the existence of certain objectives (Klein, 2012).

Data collection was done by using interviews, observation and documentation (Buska, et. al, 2018). The direct observation method was used to obtain data about the role and participation of the head of the Language Coaching Unit, the performance of language coordinators and lecturers and their implementation. Documentation was carried out to obtain data both written, image or electronic relating to the role and participation of the Head of the Language Guiding Unit in managing the laboratory, the performance of the coordinator and lecturers in managing the laboratory including facilities and infrastructure, structure and implementation of program activities. The interview used was an in-depth interview conducted to explore all specific information stored relating to the management of a language laboratory.

Using data analysis techniques, information collected were in the form of field notes (field notes), the results of interviews, researchers' comments and documentation. The steps of data analysis in the study consisted of data collection, data reduction, presentation of data and conclusions. And to facilitate the understanding of research data, the data must be presented in an organized and systematic manner.

\section{Result and Discussion \\ The Management of Language Laboratory \\ Language Laboratories' Aim and Purposes}

The Head of the Language Development Unit and the laboratory coordinator seem to have realized the function of setting the vision and mission of the language laboratory in order to improve the quality of the laboratory. From the results of observations, researchers have found the vision and mission of a written language laboratory installed in the language laboratory. So, the results of research on the vision and mission of the language laboratory illustrate that the vision and mission of the Kerinci IAIN language laboratory to date have been formulated in written form, so that each lecturer does not have a different interpretation of the vision and mission of the laboratory.

\section{The Condition of Facilities at Language Laboratory in IAIN Kerinci}

Based on the results of researchers' observations on the completeness of laboratory facilities, data were obtained that none of the equipment in the laboratory was damaged so that it could be used by students. The interview results illustrate that the language laboratory at IAIN Kerinci is in good condition and the condition of language laboratory facilities and infrastructure is sufficient to support the implementation of language learning activities, especially Arabic. Minimum laboratory standards have been met. But often the development of science and technology and the increasing number of students, laboratory equipment needs to be reproduced and rejuvenated. As well as based on the results of observations in general the condition of the Kerinci IAIN's language laboratory's conditions are good and well maintained.

\section{Planning of Language Laboratory}

The results of research on work program plans illustrate, among others: first, the work plan of the IAIN Kerinci language laboratory program has so far been arranged in standard and written, and has led to the objectives to be achieved. Secondly, there has been coordination and 


\section{Arabi : Journal of Arabic Studies}

cooperation between the head of the Language Development Unit and the leadership as well as the laboratory coordinator and between the laboratory coordinator and the language lecturer in compiling work programs for the short, medium and long term. This condition supports efforts to improve the quality of language laboratories because, without good and thorough planning, a program will not run properly.

\section{Organizing a Language Laboratory}

Determination of the structure of the language laboratory organization is carried out by the head of the language development unit through the leader. Before the organizational structure is prepared, polls are held for all lecturers as input material and by considering their performance. The people directly involved with the language laboratory organization are the heads of the language development unit, coordinators and language lecturers, especially in the listening and speaking courses. The results of research on organizing a language laboratory give the picture that the organization of language has been fully functioning as it should and the organization of language laboratories can be fully run as expected by the leadership of IAIN Kerinci. The head of the language development unit has determined its personnel by involving all staff of the language development unit involved. The administration system was impressed by the existence of a special report book on the inventory of tools and reporting on laboratory activities carried out by the coordinator in oral form. In addition, budget management also uses the principle of transparency

\section{Implementation of the Language Laboratory Work Program}

The results of research on the implementation of work programs in the language laboratory show that the implementation is carried out by referring to the work program. The administration system is also running well. The laboratory coordinator already has a book report on the inventory of tools and reporting carried out by the coordinator. And the implementation of laboratory work programs, in general, can be implemented according to the work program. The language laboratory program is implemented by lecturers as laboratory staff who want to use the facility and the Language Development Unit itself as the manager has empowered the use of the laboratory facilities.

\section{Supervision of the Work Program's Implementation}

The results of the language laboratory supervision study illustrate that in order to be able to conduct guidance, the head of the Language Development Unit must routinely carry out supervision activities to lecturers who use the language laboratory and the head of the Language Development Unit so far has given sanctions in the form of verbal and written reprimands to the lecturers who did not carry out their duties properly and regarding supervision of the implementation of the work program of the UPB head laboratory had conducted intensive and scheduled supervision. This looks to a clear schedule for the use of the laboratory it so that between the head of the Language Development Unit and the lecturers there is a good communication relationship. This situation indicates the maximum coordination between the head of the Language Development Unit and the laboratory coordinator in evaluating the deficiencies experienced by the language laboratory.

\section{Supporting Factors in Management of Language Laboratories}

The supporting factors in the management of language laboratories illustrate that first in general the Kerinci IAIN language laboratory has met the minimum standards for the university level, and in the laboratory room, a computer is available to assist the work of lecturers. Secondly, the process of procuring module books in the laboratory has been going well because each lecturer has been provided with some training in the operation of a language laboratory. Some lecturers create their own learning material. However, this material is only used by Arabic lecturers when 
teaching and learning activities take place. There is a laboratory in the room with a variety of other reference books, dictionaries and Arabic magazines that can be read and used by students to study on their own during recess. Third, the management of Arabic learning in a laboratory in the form of a column row format does not make it difficult for lecturers to monitor students sitting in the back. In addition, the number of headset devices in accordance with the number of students resulted in them being able to maximize the use of the headset device while also being able to look at the television screen.

\section{Language Laboratory Management to Increase the Competency of Arabic Language for Students}

The research on the Management of Language Labs in Increasing Arabic Language Competence in IAIN Kerinci resulted in some findings. First, the conditions regarding the general description of the language learning process at IAIN Kerinci still need to make better improvements to improve student language learning achievement by using language laboratory media. It is recommended to provide knowledge and inculcation of the level of student discipline in the language learning process so that the target can be achieved with maximum and satisfying results for students and lecturers. In this position the lecturer plays a very important role in determining the quality of the learning process as the main requirement in producing educational output.

Second, the results of the study showed that the language learning process through the laboratory at IAIN Kerinci stated that there was an increase in student listening and reading results. The use of media in the language learning process at IAIN Kerinci increases the success of student learning achievement both in the listening and reading fields. This is also shown from the attitudes and changes in student learning behavior that are more motivated by the existence of the language laboratory. The process of learning Arabic and English through a language laboratory involves several components in the room, the level of student development, subject areas and student skills in technology. in the process of learning to listen by using media that requires a high concentration of each student to understand the expressions and conversations that are exhibited by native speakers. Students are involved in socio-emotional way to understand the conversation so that they can conclude the learning process holistically; because the supports understanding the relationship between disciplines in learning to be considered and implemented. Thus, their skills or skills in the field of listening and reading are able to provide change so that learning achievement increases (Wahyudi, et.al, 2019). Another aspect that stands out from the presence of learning media was the integration of listening, reading, writing and speaking skills with an understanding of the use of learning media in each student.

Third, the language learning process through the laboratory was supported by extracurricular activities. This activity also had a positive impact on language learning achievement of students who previously did not understand said language. This shows that the efforts of language lecturers in fostering extra-curricular activities had implications for students' understanding of their development. The service of this activity was also a place for coaching that gives students more experience to further stimulate themselves in learning. Providing training, courses and other activities related to learning in this class enriched their insight, and students were able to control and understand the environment with the expertise in the language acquired.

Fourth, a place for channeling students' talent such as a laboratory is very helpful for students in the learning process. The implication seen from this media is the talent of student interest in learning is getting higher. This is because students can communicate directly with native speakers instead of the second or third person who adds to the student's insight as in the pronunciation of words or sentences in the language. The conditions and activities of the students are able to provide feedback that can train students in listening and reading. Of course, in this way students also realize the level of ability to the extent of knowledge of existing concepts or need further training. The existence of this channel of talent distribution certainly has a positive impact 


\section{Arabi : Journal of Arabic Studies}

also on the progress and understanding of students in learning languages, so that they are able to push themselves and develop existing talent.

Fifth, the implementation of the development of teaching and learning activities using the Arabic language laboratory at IAIN Kerinci was directed to students through inservice training programs. These programs include a) conducting internal coaching, b) students are required to attend coaching extra-curricular activities carried out by the campus and obeyed by all students studying at IAIN Kerinci, c) participating and involving lecturers and students to participate in various activities such as upgrading, seminars and others relating to the development of student language and understanding of student language use of language laboratory media. With the existence of coaching plat forms such as inservice training in implementing the development of student language learning achievement at Kerinci IAIN can provide benefits for students in an effort to improve their abilities. However, in-service training needs good self-improvement efforts that involve the personal readiness of students in participating in extracurricular activities, training and courses held by the campus in this case through the laboratory coordinator.

Sixth, the efforts that have been carried out by leaders and language lecturers in order to improve language learning achievement through laboratories are to improve the ability of students through the development of extra-curricular learning skills given by lecturers to students to increase learning hours. This is sought to improve the ability of students to develop Arabic language lessons which are general basic courses or MKDU. Extra-curricular activities carried out in order to improve students' language learning achievement are the inservice training program. This program includes courses or trainings conducted by leaders and language professors.

Seventh is the evaluation program conducted by Arabic or English lecturers to see the level of achievement obtained by students after they finish their studies. Assessment of learning outcomes is done in two ways, namely competitive and non-competitive. The competitive evaluation system focuses on comparing students with other students. While noncompetitive evaluation does not require comparisons between students, whether they are based on groups on mastery standards (criterion-referenced) means that lecturers provide assessments to students individually or individually. Relation to the system evaluation conducted by language lecturers in the process of learning language through laboratories. Where the learning outcomes obtained by students in order to see their ability to the extent of understanding of the mastery of listening and reading are taught. The purpose of this evaluation is also to see the feedback given by students during language teaching. And the evaluation program carried out by language lecturers every semester is able to see the weaknesses and needs of students in the language learning process through the laboratory. By knowing these needs language lecturers are able to create learning strategies to improve student language learning achievement, especially in the field of listening and reading at IAIN Kerinci.

\section{Students' Arabic Competence in Using Language Laboratory \\ Aspects of Utilization of Language Laboratories for listening activities}

Utilization of language laboratory for listening activities with the acquisition of a total score reached 267 and produced a percentage of $66.7 \%$. If interpreted at a percentage of $66.7 \%$ is between the percentages of $60-80 \%$ and included in the strong category. It can be concluded that by utilizing various learning resources in the language laboratory, it greatly helps students in listening activities.

From the results of student statements on the questionnaire it was also seen that with utilizing the language laboratory of the audio record that is played on language laboratory, can improve students' abilities in find vocabulary. In addition, students assume with utilizing the language laboratory can improve student listening skills. In this aspect, it can be concluded, increasingly the availability of a headset to the installation of audio records then students will increasingly motivated to listen to a variety of subject matter taught by. 
Aspects of Utilization of Language Laboratories for speaking activities

Utilization of language laboratory for speaking activities with the acquisition of a total scores reaching 131 and produce a percentage by $65.5 \%$. If interpreted at a percentage of $65.5 \%$ is between the percentages of $60-80 \%$ and included in the strong category. It can be concluded that by utilizing various learning resources in the language laboratory, it greatly helps students in speaking activities. From the results of student statements on the questionnaire it was also seen that as many as $65.5 \%$ agreed that using the language laboratory could make it easier for students to practice conversations with their peers, without having to face-to-face with their interlocutors. In this aspect it can be concluded, to increase student motivation in speaking using Arabic by utilizing the language laboratory to its full potential.

\section{The Success Of Managing Language Laboratories In Improving Arabic Competence}

Supporting Factors and Obstacles encountered when the process of learning Arabic through the Language laboratory

In the process of learning Arabic through the laboratory at IAIN Kerinci, the laboratory coordinator and language lecturer stated that there are various supporting factors and obstacles faced by language lecturers and students in language learning. Explained by the lecturer in the field of language studies as well as the laboratory coordinator at IAIN Kerinci stated that there are no inhibiting factors that are too heavy in the language learning process using the laboratory. This was explained at the outset because lecturers, especially language lecturers, were given special training by experts brought in by leaders to address the needs of students about the importance of using technology, which were indeed previously required experts in the laboratory media field. But in the end the lecturers are used to operating it and do not need experts who must accompany the learning process as before.

The results of research at IAIN Kerinci show that the role of language lecturers is at the level of lecturers who want to see outstanding students, as explained earlier, the obstacle itself lies with students, where they do not feel happy with Arabic subjects because it is not a language that is used daily day which caused less interest in learning even though it was equipped with learning media. Many students are active in the language learning process through the laboratory but there are also students who are not active which causes the concentration of other students to be disrupted. This problem is one of the factors inhibiting the process of language learning through laboratories felt by lecturers and other students. The supporting factors of the learning process through the laboratory that need to be maintained by language lecturers in order to achieve learning objectives include high lecturer interest in providing good education to students, procurement of media in the learning process, extension of study hours and activities outside of other class hours.

\section{Efforts made by language lecturers to improve student learning success through the Language Laboratory}

One of the efforts of lecturers and coordinators in order to improve student language learning achievement at IAIN Kerinci is through the development of student training in information and communication technology. The development of student skills at IAIN Kerinci is carried out with education and position programs (inservice training). Training and course activities on the use of communication information technology to students are expected to be able to provide new insights to students in using learning media. Thus, the language learning process using a laboratory can take place communicatively and actively as well as the feedback from students.

There are three ways that can be done in connection with the inservice training program, namely 1) opening services for students to get teaching about the use of technology in the form of software and hardware; 2) service training carried out through training programs or extra- 


\section{Arabi : Journal of Arabic Studies}

curricular activities both conducted by the college itself and the independent efforts of students; 3 ) activating the coaching and development of student skills by opening special workshops for students studying at the college. The development of this workshop is to provide guidance and counseling and training to improve student achievement in the field of students.

The efforts to improve success in managing language laboratories were made by language laboratory coordinators and language lecturers in order to improve student learning success by procuring language laboratories at IAIN Kerinci by including them in the inservice training program by following educational programs and training and courses held by language lecturers outside of class hours. Besides that, one of the strategic coaching platforms when viewed in terms of time and cost in order to improve the success of student languages, especially in teaching listening and reading, was through the workshop coaching forum held by internal campus.

\section{Conclusion}

The general conclusion of this research is that the management of the Kerinci IAIN language laboratory in general has run according to the existing provisions. However, there are still a number of things that need to be addressed. First, the vision and mission of the language laboratory in Kerinci IAIN has been formulated in writing. Secondly, the conditions of facilities and infrastructure of language laboratories are sufficient and sufficient to support the implementation of language teaching and learning activities, especially Arabic. Third, planning of the work program of the IAIN Kerinci language laboratory is less structured. Fourth, the organization of language laboratories has not been fully implemented as expected by the leadership of the IAIN Kerinci even though the head of the Language Development Unit (UPB) has determined its personnel by involving all UPB staff involved. Fifth, the implementation of laboratory work programs in general is also not yet running. The sixth, supervision of the implementation of the work program of the head of the Laboratory of Language Development Unit has never conducted intensive and scheduled supervision. Seventh, supporting factors are the existence of language laboratory equipment assistance from the government, funds available but not utilized by the management. The inhibiting factor was that the manager did not try to submit a proposal for submission of funds to the IAIN Kerinci for the supply and propagation of laboratory equipment.

The suggestions are proposed. First, the ability and skills of lecturers need to be improved through training on the management of language laboratories. Then, the administration of language laboratories needs to be addressed, given the importance of knowing the state of the laboratory equipment. Third, the maintenance and arrangement of room layout should be prioritized and improved. Finally, Heads of Language Development Units need to intensify the guidance and supervision of the management of language laboratories in an effort to improve the quality of the Language Development Unit itself in general.[]

\section{References}

Albantani, A.M. 2018. Pembelajaran Bahasa Arab di UIN Syarif Hidayatullah Jakarta: Teori dan Praktik. Tangerang Selatan: Cinta Buku Media.

Albantani, A.M., \& A. Madkur. 2019. "Teaching Arabic in the era of Industrial Revolution 4.0 in Indonesia: Challenges and opportunities", ASEAN Journal of Community Engagement, Vol. 3, No. 2.

Allen, Lynn C. 2013. "Role of a Quality Management System in Improving Patient SafetyLaboratory Aspects", Clinical Biochemistry, Vol. 46, No. 2.

Berrett, Bryan. 2012. "Using Computer-Assisted Language Learning in an American Sign Language Course", Innovation in Language Learning and Teaching, Vol. 6, No.1. 
Berte, Lucia M. 2007. "Laboratory Quality Management: a Roadmap", Clinics in laboratory Medicine, Vol. 27, No. 4.

Bolanakis, D.E., E. Glavas, and G.A. Evangelakis. 2007. "An Integrated Microcontroller-Based Tutoring System for a Computer Architecture Laboratory Course", International Journal of Engineering Education, Vol. 23, No. 4.

Brenes, C.A.N. 2006. "The language laboratory and the EFL course", Revista Electrónica Actualidades Investigativas en Educación, Vol. 6, No. 2

Buska, Wahyudi., Yogia Prihartini, \& Nur Hasnah. 2018. "Dirâsah Tahlîliyyah Taqwîmiyyah 'An al-Mufradât fî Kitâb Manân al-Azîz", Arabiyat: Jurnal Pendidikan Bahasa Arab dan Kebahasaaraban, Vol. 5, No. 2.

Dakin, Julian. 1973. The Languange Laboratory and Languange Learning. London: Longman.

Decaprio, Richard. 2013. Tips Mengelola Laboratorium Sekolah. Yogyakarta: DIVA Press.

Fulga, Netta. 2013. "Quality Management and Accreditation in a Mixed Research and Clinical Hair Testing Analytical Laboratory Setting - A Review”, Therapeutic Drug Monitoring, Vol. 35, No. 3.

Grunig, James E. 2006. "Furnishing the Edifice: Ongoing Research on Public Relations as a Strategic Management Function”, Journal of Public Relations Research, Vol. 18, No. 2.

Halimah, R.A., Umi Saktie, \& Ibnu Hadjar. 2018. “Arabic language learning evaluation in higher education with context input process product (CIPP) model”, Alsinatuna, Vol. 4, No.1.

Hofstein, Avi., \& Vincent N. Lunetta. 2004. "The Laboratory in Science Education: Foundations for The Twenty-First Century", Science Education, Vol. 88, No. 1.

Kashada, A., H. Li, \& O. Koshadah. 2018. “Analysis Approach to Identify Factors Influencing Digital Learning Technology Adoption and Utilization in Developing Countries", International Journal of Emerging Technologies in Learning (iJET), Vol. 13, No.2

Klein, Laura., Nan Li, \& Burcin Becerik-Gerber. 2012. "Imaged-Based Verification of As-Built Documentation of Operational Buildings", Automation in Construction, Vol. 21, No. 1.

Leite, Laurinda., \& Luís Dourado. 2013. "Laboratory Activities, Science Education and ProblemSolving Skills”, Procedia-Social and Behavioral Sciences, Vol. 106, No. 1.

Marzuki, Marlina. 2014. "Managing an Effective English Language Laboratory in a Polytechnic", Studies in English Language and Education, Vol. 1, No. 2.

Prihartini, Yogia., Wahyudi, Aliasar, Mukhaiyar, and A.O.M. Ungsi. 2018. "The Development of Arabic Learning Model by Using Multimedia of Computer at UIN STS Jambi”, Al-Ta'lim Journal, Vol. 25, No. 2.

Prihartini, Yogia., Wahyudi Buska, \& Nur Hasnah. 2019. "Analysis of Test Item on The Final Test Semester Exam on Arabic Subjects", Arabiyat: Jurnal Pendidikan Bahasa Arab dan Kebahasaaraban, Vol.6, No. 1.

Ramganesh, E., \& S. Janaki. 2017. "Language Laboratories: A Milestone in Higher Education", International Journal of Academic Research in Management (IJARM), Vol. 6, No. 2.

Rosnita, R. 2016. “The Development of Laboratory-based Earth and Space Science Learning Model to Improve Science Generic Skills of Pre-service Teachers", Jurnal Pendidikan IPA Indonesia, Vol. 5, No. 2.

Tobin, Kenneth. 1990. "Research on Science Laboratory Activities: In Pursuit of Better Questions and Answers to Improve Learning", School Science and Mathematics, Vol. 90, No. 5. 
Arabi : Journal of Arabic Studies

Vanderplank, Robert. 2010. "Déja vu? A Decade of Research on Language Laboratories, Television and Video in Language Learning", Language Teaching, Vol. 43, No. 1.

Wagener, Debbie. 2006. "Promoting Independent Learning Skills Using Video on Digital Language Laboratories", Computer Assisted Language Learning, Vol. 19, №. 2.

Wahyudi., \& Yogia Prihartini. 2019. "Development of Arabic Learning Material Based on Eclectic Method", 3rd Asian Education Symposium (AES 2018): Atlantis Press. 